Article

\title{
How Construction Employment Can Create Social Value and Assist Recovery from COVID-19
}

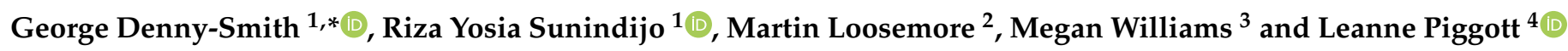 \\ 1 UNSW Built Environment, University of New South Wales, Sydney 2052, Australia; r.sunindijo@unsw.edu.au \\ 2 School of Built Environment, University of Technology Sydney, Sydney 2000, Australia; \\ Martin.Loosemore@uts.edu.au \\ 3 National Centre for Cultural Competence, Sydney University, Camperdown 2006, Australia; \\ megan.williams@sydney.edu.au \\ 4 UNSW Business School, University of New South Wales, Sydney 2052, Australia; 1.piggott@unsw.edu.au \\ * Correspondence: g.denny-smith@unsw.edu.au
}

Citation: Denny-Smith, G.; Sunindijo, R.Y.; Loosemore, M.; Williams, M.; Piggott, L. How Construction Employment Can Create Social Value and Assist Recovery from COVID-19. Sustainability 2021, 13, 988. https://doi.org/10.3390/su13020988

Received: 16 December 2020

Accepted: 14 January 2021

Published: 19 January 2021

Publisher's Note: MDPI stays neutral with regard to jurisdictional claims in published maps and institutional affiliations.

Copyright: (c) 2021 by the authors. Licensee MDPI, Basel, Switzerland. This article is an open access article distributed under the terms and conditions of the Creative Commons Attribution (CC BY) license (https:// creativecommons.org/licenses/by/ $4.0 /)$.

\begin{abstract}
COVID-19 has created or amplified economic and social crises internationally. Australia entered its first recession in 30 years and saw a significant rise in unemployment. In response, Australian governments have increased their commitments to infrastructure construction to stimulate the national economy and combined this with new social procurement policies that aim to create social value for targeted populations like Indigenous peoples and unemployed youth. However, emerging social procurement research in construction shows a disconnect between policymakers and the practitioners who must implement them. Therefore, the aim of this paper is to provide theoretical and practical insights on creating social value in the context of construction employment created by new social procurement policies. Reporting a survey of 107 construction workers in Australia, it is shown that social procurement policies and construction employers can create social value when they provide work benefits like adequate pay and training and development and cultural benefits like inclusive workplaces. Recommendations are made to demonstrate how the results presented in this article can be used by contractors to create social value. This research is significant for advising how increased infrastructure spending commitments in Australia can create social and economic outcomes for workers, ensuring a sustainable recovery from COVID-19 crises.
\end{abstract}

Keywords: construction employment; COVID-19; infrastructure investment; social procurement; social value

\section{Introduction}

The year 2020 saw the magnification of existing complex issues in societies globally. Australia was placed into its first recession in 30 years because of the COVID-19 pandemic [1]. Unemployment in Australia reached a 20-year high of 7.5\% in July 2020 [2] and Australians who found themselves suddenly unemployed have had to deal with an 'inadequate' income support system that 'impede[s] peoples' ability to engage socially and economically within their community' [3] (p. xvii). COVID-19 has thus created significant adverse social and economic impacts, particularly on vulnerable Australians like the long-term unemployed [4]. While Indigenous Australians are included in lists of groups vulnerable to COVID-19, Indigenous-led responses have mitigated the incidence of COVID-19 in Indigenous communities [5].

As several authors have noted, COVID-19 has forced societies globally to develop new social practices and ways of living, such as working from home, social distancing, and self-isolation [6,7]. These changes have occurred at the same time as significant job losses as economies are impacted by the large numbers of job losses that have occurred. There is thus an urgent need for greater attention to encourage innovations that create social value to reduce the impacts of COVID-19 [8]. In particular, as Bacq et al. [9] stated, 
COVID-19 has created an opportunity to promote collaborative endeavours that create social value. It is therefore timely to investigate how social value can be created through major industries like construction to ensure sustainable development and recovery from COVID-19. Research on the economic and social recovery COVID-19 may also benefit from acknowledging the Indigenous values and ways of doing that have underpinned successful Indigenous-led responses to COVID-19 in Australia. This article thus contributes to the journal's aims of economic and social sustainability and will highlight how business prosperity can be achieved through socially sustainable practices.

In response to these issues and being aware that they could delay Australia's social and economic recovery from the COVID-19, Australian governments have committed to new infrastructure investments to stimulate employment and the economy. In addition to the AUD 110 billion committed to infrastructure funding and financing over 10 years from 2020-21 [10], these responses include approximately another AUD 77 billion in infrastructure commitments by state and federal governments:

- An AUD 1.5 billion investment package for 'Shovel Ready' projects such as road and transport upgrades and construction in the twelve months after Australia's economy experienced the first economic impacts of the pandemic [11].

- A total of AUD 11 billion brought forward to support future development around the Western Sydney Aerotropolis, in partnership with the New South Wales (NSW) Government [12].

- A total of AUD 52 billion was committed to new infrastructure construction as part of Queensland's economic recovery plan out of COVID-19 [13].

- A total of AUD 12.9 billion was dedicated in South Australia to infrastructure investments between 2020-2024 in recognition of the 'role infrastructure can play in the recovery phase through direct employment in infrastructure projects as well as positioning the economy to rebound quickly' from the impacts of the COVID-19 crisis [14] (p. 2).

There has therefore been a large increase in construction activity during the pandemic, driven by government commitments to increase their construction spending to stimulate the economy in response to COVID-19, and the construction industry is currently among the more stable industries at a time of economic uncertainty. These significant investments have also provided an opportunity for Australian governments to partner their construction spending with new social procurement policies that require contractors to create social value in the communities in which they build [15]. Social procurement involves new partnerships between governments and the private sector to create social value through traditional market practices [16]. Governments create social value via direct employment of groups targeted by social procurement or indirectly by inserting social procurement clauses into supplier contracts [17]. In construction, this involves requiring contractors to employ or purchase from the groups that social procurement policies target, like Indigenous Australians [18], social enterprises, or Australian disability enterprises [19]. Indigenous procurement is a major component of social procurement in Australia, with the Australian Government's Commonwealth Indigenous procurement policy generating more than $\$ 3.5$ billion AUD in contract opportunities for Indigenous businesses since its introduction in July 2015 [20]. The social value that construction creates typically refers to the economic, social, and cultural impacts of a project in the community in which it is built [15] and, for example, the targeted social value of social procurement policies like the Commonwealth Indigenous procurement policy in Australia is the economic development of Indigenous Australia through increased business and employment opportunities [18]. This paper focuses on the social value created by construction employment because the large infrastructure projects committed by Australian governments are expected to create several thousand jobs, as the above references indicate.

Despite the interest in social value, it remains an underexplored area because, as Mulgan [21] (pp. 38-40) stated, social value is inherently 'subjective, malleable and variable' in nature and means different things to different people based on their ethics, morals, and 
priorities. This is especially true in construction, where the potential social value of social procurement is undermined in practice by stakeholder nervousness about policy design, stability and implementation, poor risk management, information asymmetries, and perverse incentives [22]. Social procurement in construction is also inconsistent because practices are not internalised across organisations, and projects and the people targeted by social procurement may only be hired on to comply with contractual social procurement requirements [23]. Creating social value through construction procurement is also hampered by the lack of policy direction and a clear definition of what social value is and how it can be created [24]. Deciding what social value is in a specific social procurement policy context remains challenging because, as Watts et al. [25] noted, different stakeholders have competing social value objectives, and this creates difficulties for contractors and policymakers seeking to measure and report on social value outcomes. As Raiden et al. [15] argued, social value remains a theoretically and operationally ambiguous concept. It is therefore not evident whether the social procurement policies that will be enacted with the commitments outlined above will create social value and contribute to the social recovery from COVID-19.

Simultaneously with the above arguments about the theoretical and operational understanding of social value, there is a need for data innovations to understand the human, social, and economic impacts of COVID-19 while tracking progress towards the United Nations' Sustainable Development Goals [26]. Without understanding how the construction employment created by significant infrastructure commitments by Australian governments can be used to create social value, government efforts to leverage significant construction investments and manage economies out of the economic and social crises of COVID-19 may be unsustainable, potentially delaying international recovery efforts. The Australian construction industry is the focus of this study because of the very significant increases in government spending on infrastructure construction to stimulate the economy in response to COVID-19.

In the above context, and with the aim of contributing to the success of global efforts to recover from the crises created by COVID-19, this paper aims to provide theoretical and practical insights into how construction procurement creates social value through employment in Australia. More specifically, this paper will answer the following research questions:

1. What are the contributing factors to creating social value through construction employment?

2. What is the relationship between construction employment outcomes and social value?

This research is important for a sustainable recovery from the human, social, and economic impacts of COVID-19 and driving innovations to progress the eighth Sustainable Development Goal 'Decent work and economic growth'. This type of research is also critically important given the importance of infrastructure investments to stimulate economic activity post-COVID-19 [27]. This will ensure the prosperity of business internationally as economies and societies recover from the global pandemic.

\section{Literature Review}

While not new [28], social procurement has been described as a social policy innovation to create social value through partnerships between governments, businesses, and civil society [29]. Governments create indirect social value by requiring contractors working on large infrastructure projects to use local disadvantaged people as workers on-site or in their supply chains [29]. In construction, this means contractors are increasingly being required to demonstrate the social value they create when tendering for public sector projects and for socially responsible private clients.

There are five critical drivers to the increasing use of social procurement in construction:

- The historical use of public procurement to achieve social outcomes [30];

- A receding welfare state in the context of New Public Governance (NPG) [16]; 
- Increased focus on evaluation and measurement of social performance in order to command legitimacy with government funders [16];

- Recognition that construction work often operates in areas of significant disadvantage and purchasing construction materials, professional services, and contractors has significant potential to address complex problems and create social value $[31,32]$ (p. 82); and

- An increasing number of socially responsible private clients in the context of growing corporate social responsibility practices [15].

Despite the growing importance of communicating the social value that construction creates, its subjective nature has caused difficulties in measuring and reporting it to clients and governments. This is especially relevant in the context of emerging construction social procurement requirements which require firms to create social value by providing employment opportunities for targeted groups such as Indigenous peoples who come from different cultures which see value differently [33]. In addition, social outcomes of construction procurement are often intangible [34], which presents difficulties for construction clients seeking to evaluate the social value that their procurement creates. This has resulted in many definitions of what social value is and how it is created, which has complicated attempts to understand social value conceptually and operationally [15]. Troje and Gluch [35] argued that this means there is often little to no follow-up by construction clients on the social value of their social procurement policies.

Given the above challenges, several recent attempts have been made to better conceptualise and understand what social value means in a construction context. For example, Raiden et al. [15] (p. 17) provided a critical review of definitions from different fields and defined social value as 'the social impact of any construction organisation, project or program makes to the lives of internal and external stakeholders affected by its activities'. Nicholls [36] (p. 148) theorised that accounting for social impact should give voice to and empower people through 'the materiality of uncertainty data ... via careful stakeholder engagement ... that acknowledges the empowering potential of such processes as communicative action'. Watts et al. [25] developed a social value tool which could be understood by numerous stakeholders simultaneously. More recently, Denny-Smith et al. [33] argued that social procurement policies will create social value when the policies support the ways of knowing, being, and doing of the groups they are meant to benefit. Denny-Smith et al. [33] presented a conceptual framework to plan, implement, and evaluate social procurement by consulting with affected stakeholders at all stages of a project's lifecycle.

As Denny-Smith et al. [37] argued, it is too often those in a position of power who determine what social value is and how it should be measured. This excludes the perspectives and experiences of people meant to benefit from social value practices. In addition, there are also many controversies around existing econometric tools that attempt to quantify and monetise social value, such as social return on investment (SROI), or other prescriptive metrics which Watts et al. [25] criticise for being too reductionistic and overly simplistic by aiming to combine social impacts into a single financial value. As Raiden et al. [15] discussed, inherent problems exist in traditional econometric approaches to measuring and monetising social value, such as failing to reflect personal notions of value which are often highly subjective. This reflects the lack of social value theory where, in the social sciences generally, Haugh [38] argued that good theory development will lead to good practice. To begin developing insights on creating social value through construction employment and differentiate social value creation from traditional econometric approaches which can be simplistic and reductionist that will lead to improved policy and practice, the following sections describe a new theoretical framework which provides theoretical and practical insights to create social value. This will help existing tools to be adapted to communicate the true impacts that social value practices have on the people they are meant to benefit. 


\section{Conceptual Framework}

Meinong's [39] value theory is particularly useful in conceptualising social value creation because it proposes four components acting together in a process of determining value-(1) value subject: a person perceiving the social value created by social procurement policies or construction employment opportunities the policies provide; (2) value object: the construction employment opportunities provided by social procurement policies which will be given a social value; (3) existence judgement: an evaluation of the relationship between the value object (construction jobs) and someone's personal and cultural values that determines the social value created by social procurement policies, and; (4) value feeling: a person perceiving the social value that construction employment creates based on the relationship between a value object (a job) and the existence judgement.

While useful for conceptualising the notion of value, Meinong's [39] theory was not developed in a social value context which, as discussed above, is linked in the construction sector primarily to the creation of employment opportunities for disadvantaged groups targeted by social procurement policies. Meinong's theory also does not consider that social value is determined by 'work benefits' and 'cultural benefits' that arise from construction employment [40]. Work benefits are more tangible and include things like training, autonomy, and fair remuneration. Cultural benefits include good working relationships, promoting employees' sense of autonomy and identity, and organisational values and their engagement with local communities, in addition to cultural variables such as workers' cultural identity and culturally supportive work environments that, as Denny-Smith and Loosemore [40] argued, influence the social value people perceive from employment. In this context, social value is created through employment which meets the employment and cultural needs of those targeted by these policies, and research in the area of employer of choice (EOC) may hold some value in adapting the theory to a construction environment. Founded in efficiency wage theory, the concept of EOC suggests that workers have a choice of where to work and realise that different choices will likely lead to different levels of success and job satisfaction. Workers will therefore choose employment where they can take advantage of their skills and there is a balance between theirs and the organisation's values [41].

A review of the EOC research indicates that they generally include various combinations of several criteria. Branham [42], attempting to show how companies can become EOCs, suggests four strategic areas where companies can become EOCs based on shortterm, long-term and tangible and intangible benefits, as shown in Table 1.

Table 1. Strategic employer of choice (EOC) characteristics [42].

\begin{tabular}{ccccc}
\hline & & Short-Term & \multicolumn{1}{c}{ Long-Term } \\
\hline \multirow{2}{*}{ Tangibles } & $\bullet$ & Base pay & & Stock options \\
& $\bullet$ & Yearly incentives & $\bullet$ & Profit-sharing plans \\
& $\bullet$ & Health insurance & $\bullet$ & Pensions \\
& & & & \\
Intangibles & $\bullet$ & Work-life balance & $\bullet$ & Work climate/culture \\
& $\bullet$ & Hiring practices & $\bullet$ & Supervisor behaviour \\
& $\bullet$ & New hire engagement & $\bullet$ & Trust in leaders \\
& & & \\
\hline
\end{tabular}

Kucherov and Zavyalova [43] investigated employer of choice attributes from four perspectives-economic, psychological, functional, and organisational. These characteristics are described below:

- Economic: high salary, fair rewards and bonus system, and appropriate work schedule;

- Psychological: strong supportive corporate culture, favourable relationship among employees, teamwork, and objective evaluation of the work itself; 
- Functional: training, career growth, career development, and utilisation of employees' knowledge and skills;

- Organisational: market leadership, scope of international operations, products brand reputation, management style, and reputation of top management.

Elving et al. [41], researching the relevance of employer branding to becoming an EOC, explored five variables in their study, which are explained in Table 2.

Table 2. EOC characteristics and their implications for social value research based on Elving et al. [41].

\begin{tabular}{cl}
\hline EOC Characteristic & \multicolumn{1}{c}{ Description } \\
\hline - $\quad \begin{array}{l}\text { Whether potential employees see a company as a desirable } \\
\text { and positive place to work; }\end{array}$ \\
- $\begin{array}{l}\text { Individuals have different needs, therefore they will be } \\
\text { attracted to organisations that meet those needs; }\end{array}$ \\
Organisational attractiveness \\
Organisational attractiveness is dependent on how a \\
company advertises itself to potential employees, and \\
organisations that meet the needs of their employees are \\
therefore more likely to create social value.
\end{tabular}

- $\quad$ EOCs are companies that share similar characteristics and attitudes to employees;

- $\quad$ Typical characteristics include a supportive working

Job and organisational characteristics and person-organisation fit

Employer image

Employer branding environment, ethical standards, salary, career prospects and location, compensation, culture and training, and development possibilities;

- Jobs in which an employee is a good fit are more likely to create social value because the company's values and ways of working support those of the employee.

- Positive corporate image perceptions increase organisational attractiveness by signalling positive job attributes, therefore increasing the quality and quantity of candidates;

- $\quad$ Companies with a good corporate image are more likely to be EOCs because of more employee pride derived from their association with the company.

- Employer image refers to a company's reputation as an employer in the labour force;

- $\quad$ This can differ from a company's corporate image when people move to being employed by a company where, for example, working conditions may not be what they were advertised or the company culture is not what they that it was.

- $\quad$ Employer branding serves as a management framework that can help improve employee recruitment, retention, and commitment in addition to increasing productivity;

- In the context of social value, companies with good employer branding are likely to create social value if employees get more satisfaction and enjoyment from their work.

More recently, Bellou et al.'s [44] research found that critical EOC factors include the following workplace characteristics: 
- $\quad$ Self-development: the company has a learning orientation, provides career coaching and advice, encourages the dissemination of knowledge, and there is a clear emphasis on the development of skills;

- Corporate image: from a commercial perspective, the company is financially solid, develops innovative products and services, and is market oriented. From a social perspective, this means the company is sensitive to social issues and oriented towards protecting the environment;

- Recognition: new hires feel welcome and important, employees' creativity is recognised and utilised, management realises and recognises the overall contribution of employees, and employees feel important and identifiable and employees are given opportunities to apply their knowledge in the business;

- Relationships: relationships with colleagues are factual and active, mutual respect is shown, and there is sincere communication among employees. Managers have employee relationships with proper guidance is provided, meritocracy is practiced, and managers recognise the efforts of staff;

- $\quad$ Remuneration: the company provides supplementary non-financial benefits, attractive salary packages, and above-average wages.

Investigating the factors that contribute to a company being branded an employer of choice, Aboul-Ela's [45] findings developed four dimensions of importance to graduates and workers when selecting a potential employer:

- 'Bloom' represents the apparent factors outside the organisational boundaries. These factors appear to the general public as well as to potential employees about the organisation. The Bloom dimension includes employer reputation, corporate social responsibility practices, positive image conveyed to the general public, type of industry, scope of international operations, comprehensive website, the employer's status as a market leader, range of products and services, the employer's ability to differentiate itself from competitors, its vision, mission, and core values, and the ability to maintain a positive reputation;

- 'Live' is the actual working environment where employees operate. This revolves around hygiene factors with respect to the working conditions essential for job functioning and execution. The Live dimension includes salary scheme, fair rewards and bonus system, appropriate compensation, sense of workplace empathy and compassion, pleasant working place, supportive corporate culture, fair holidays, appropriate retirement packages, dynamic business process, work-life balance, and good industrial health and safety programs;

- 'Connect' revolves around the aspects tied to the interactional relationship between the employee and the organisation. This dimension is realised through existing employees and sometimes conveyed through word-of-mouth outside the organisational boundaries to the external community. The Connect dimension includes caring about employees' well-being, adopting teamwork and team spirit practices, a positive image conveyed through existing employees to the general public, management style and interaction with employees, and employers' ability to fulfil obligations towards employees;

- 'Grow' is concerned with the factors related to an employee's potential growth, selfdevelopment, and progression in the workplace. The Grow dimension includes long-term career development opportunities, jobs with task variety, challenging opportunities to grown and learn, training and development opportunities, utilisation of employees' knowledge and skills, objective evaluation, feedback for employees' development, and job security that allows for future growth.

In the field of marketing, Rampl's [46] research found that EOCs are identified by university students and graduates based on work content and work culture. Work content refers to core work activities, while work culture refers to the working environment and relationships between employees [46]. Regarding this, Pacheco and Webber [47] found that participative decision-making in workplaces increases job satisfaction, which could lead to 
a better work environment and work content. Garcia et al. [48] also found that younger workers (i.e., millennial workers) prefer employers and workplaces where there is greater employee involvement and they can apply their knowledge and skills in the workplace, again leading to more interesting work content and a better work environment.

The above review of the general EOC literature indicates that, in the context of creating social value through construction employment, EOCs may create social value when they provide work benefits and cultural benefits. While this paper does not explicitly focus on a particular group, Indigenous values like reciprocity and respect $[49,50]$ have informed this study's design, operation, and reporting because of the major focus in Australia on increasing Indigenous employment through social procurement policies. This is not to exclude other minorities' perceptions of value from social value research, which can be incorporated in future research and contrasted with these findings. Respect was demonstrated by incorporating stakeholders' comments into the research design. Reciprocity was demonstrated by providing summaries to research stakeholders and through ongoing collaboration on research about social value in construction.

Synthesising the above critical review of EOC literature that highlights the worker values and job and employer characteristics relevant to EOCs, Figure 1 below presents that conceptual framework that is explored in this study. Starting with construction jobs created by social procurement policies on projects initiated by the recent boosts in government spending on construction projects, Figure 1 is split into and summarises the worker values and EOC characteristics that the literature review shows are likely to create social value for construction workers. For example, drawing on the above review, Figure 1 summarises that worker values that are likely to create social value include variables relating to workplace culture and relationships, inclusive work environment, etc. Below the worker values are the EOC characteristics likely to create social value, such as level of income, people's work environment, and training and development opportunities provided to staff. Because value theory shows that social value is perceived based on workers' acceptance or rejection of these variables, it is necessary to understand the weighting of importance that construction workers place on them. The process of surveying construction workers to understand the importance of these variables to social value is detailed in Section 3 below.

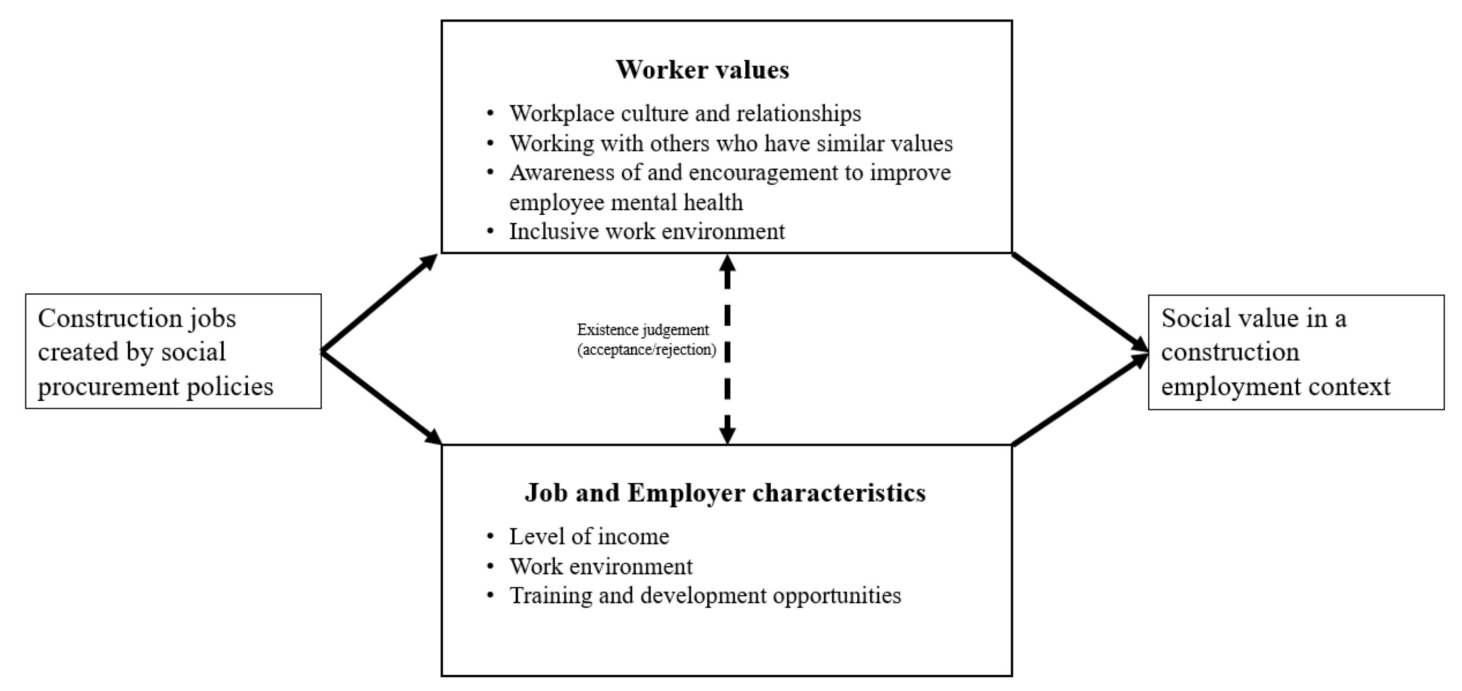

Figure 1. A conceptual framework to explore how social value is created in the context of construction employment.

While useful, the EOC field remains generic and, as Hunter [51] noted, research on the relationship between populations targeted by social procurement (like Indigenous workers in Australia) and their employers is scarce. Indeed, EOC research does not provide insight into the employment attributes that workers seek in specific industry sectors such as construction which represents the focus of social procurement policies. While Sedighi and 
Loosemore [52] explored EOC characteristics in construction from a graduate perspective, there has been no research into the types of employment which are likely to maximise social value in a construction context.

\section{Method}

Based on an in-depth review of the EOC literature and working with two construction companies as participating organisations, an anonymous online survey of construction workers in Australia was used to explore the employment conditions which would create maximum social value in the construction industry. A survey tool was employed after consultation with participating organisations in the Australian construction industry. The two organisations were based in the Australian state of New South Wales. One of the industry partners has worksites across Australia, and the partners' involvement allowed the research team to maximise the reach of the recruitment and data collection strategy. Online surveys offered several benefits to partnering organisations, including reducing costs to distribute and collect survey responses from geographically dispersed sites in regional areas of Australia where staff were based, maximising survey coverage to the target sample population, improving response rates because of improved ease to complete the survey, and reducing social desirability bias [53], to attain objective insights into social value within the construction industry.

\subsection{Survey Structure}

The survey consisted of two sections, and respondents were identified and approached through partner contracting organisations using purposive nonprobability sampling on the basis of their employment in the construction and property maintenance industries. The first part of the survey asked demographic questions about age, cultural identity, and the state or territory they worked in. The second part of the survey asked respondents about their values based on the research by Bellou et al. [44] which showed that EOC's have values that are strongly aligned with the values of employees and include, for example, interpersonal relationships within the company, relationships between the employer and employees, and relationships of the employer company to society/communities. In Australia, this includes attitudes towards family, communities, and obligations to society that differ between cultural groups in that country (see for example [54]). Following value theory's argument that values have a critical role to play in determining value, and to answer research question two, the purpose of the second part was to understand the values of respondents and make inferences about the workplace values that are likely to facilitate creating social value.

The third part of the survey asked respondents to rank the importance of 31 EOC characteristics from the results of EOC research on construction graduates by Sedighi and Loosemore [52] and based on a four-point Likert scale. The four-point scale was used as a forced-choice question that makes respondents choose an option for or against a question [55]. Forced-choice questions were used in this survey to minimise the risk of social desirability bias and helped highlight respondents' relationships between different questions [56]. The questions in this part of the survey were adapted to include social and cultural variables which research on 'old institutionalism' [57] indicated people consider when perceiving social value. For example, research on successful employment programs for minority populations, such as Indigenous Australians, shows that cultural benefits of employment opportunities include culturally safe and supportive environments, having clear career progression pathways for employees, positive engagement with employees' heritage, family and community, and boosting employees' confidence, autonomy, selfefficacy, identity and resilience [58]. Recognising the subjective nature of social value and the lack of research into what construction employees may want out of an EOC, one open question was included to allow respondents to insert EOC variables not covered in the closed questions. 
After developing the semi-structured survey with the above cultural variables, industry partners were consulted for further discussion on how data would be collected and managed. For example, the research team took direction from industry stakeholders on the format of the survey, and a shared agreement was reached that the content was accurate to investigate social value in a construction context, thus improving the content validity of the survey [59] (p. 139). The research team explained that data would be stored and managed in accordance with ethical approval.

\subsection{Sampling}

The survey was distributed to 190 people working for two industry partners across Australia, using purposive sampling to ensure the survey was distributed to workers in the construction industry. Sampling construction employees allowed a broad sample representation for this exploratory research on social value in the construction industry. To maximise the response rate, an email was sent to each respondent with an invitation letter which ensured respondent anonymity and allowed them to ask any questions of the research team and withdraw their data at any time. Active efforts to collect data resulted in a total of 107 usable survey responses (a response rate of 56 per cent), producing a sample as illustrated in Table 3.

Table 3. Survey sample structure.

\begin{tabular}{cccc}
\hline Category & Response & Frequency & Percentage \\
\hline \multirow{2}{*}{ Australian citizen } & Yes & 95 & 88.8 \\
& No & 12 & 11.2 \\
\hline \multirow{3}{*}{ Australian state or territory } & ACT & 4 & 3.7 \\
& NSW & 79 & 73.8 \\
& QLD & 11 & 10.3 \\
& SA & 2 & 1.9 \\
& TAS & 1 & 3.9 \\
\hline
\end{tabular}

\subsection{Analysis}

Survey data were analysed using IBM's quantitative data analysis tool Statistical Package for Social Sciences version 24. Descriptive analysis was completed on the data to show the highest-ranked variables. A bivariate correlation test using Pearson's correlation coefficient (Pearson's $r$ ) was performed to test for relationships between the values and EOC variables. The results of this analysis are presented below.

\section{Results}

\subsection{Contributing Factors to Create Social Value}

In this section, the results relating to the first research question are presented. Following value theory and the role of values and workplace characteristics in determining value, ranked scores are presented for the survey sections relevant to these variables. This identifies the top variables contributing to social value in the context of construction employment in Australia. Because 107 completed responses were received, the data satisfy the central limit theorem [55] and can be assumed to be normally distributed. Table 4 below shows respondents' values ranked by order of mean. Table 4 shows that the five highest-rated values were 'sharing with and looking after my family', 'finding things out and learning for myself', 'making sure I have enough for today', 'knowing who I am and where I came from', and 'respecting my elders and what they have to teach me'. The highest-rated variables were also characterised by a lower standard deviation than other responses, indicating a high degree of consensus among respondents. 
Table 4. Construction workers' values ranked by mean.

\begin{tabular}{ccc}
\hline Value & Mean & Rank \\
\hline Sharing with and looking after my family & 3.82 & 1 \\
Finding things out and learning for myself & 3.73 & 2 \\
Making sure I have enough for today & 3.56 & 3 \\
Knowing who I am and where I came from & 3.48 & 4 \\
Respecting my elders and what they have to teach me & 3.38 & 5 \\
Building wealth for future purposes (i.e., tomorrow and beyond) & 3.36 & 6 \\
Staying connected with my wider relatives and community & 3.23 & 7 \\
Travelling widely and experiencing the world & 3.20 & 8 \\
Sharing with and looking after my community & 3.16 & 9 \\
Making sure traditions, rituals, and practices are maintained & 2.88 & 10 \\
Making lots of money & 2.73 & 11 \\
Having possessions (like a house, car, fashion items) to show & 2.46 & 12 \\
my status & 2.43 & 13 \\
Staying close to the place I was born & 2.27 & 14 \\
\hline
\end{tabular}

Table 5 shows respondents' EOC preferences ranked by order of mean score. Similar to Table 4, the highest-ranked EOC preferences had the lowest standard deviation, indicating that those preferences were regularly ranked more important by respondents. It was interesting that only five $\mathrm{EOC}$ variables had a mean below 3 , i.e., on average the respondents ranked most EOC variables as Important.

Table 5. Construction workers' EOC preferences ranked by mean.

\begin{tabular}{|c|c|c|}
\hline EOC Preference & Mean & Rank \\
\hline Good quality of working relationships & 3.85 & 1 \\
\hline Seeing and understanding the overall purpose of tasks & 3.78 & 2 \\
\hline A good reputation & 3.76 & 3 \\
\hline High level of personal physical safety & 3.73 & 4 \\
\hline Being able to learn on the job & 3.71 & 5 \\
\hline A manager that focuses on leadership and energy in the workplace & 3.68 & 6 \\
\hline Clear pathways for me to progress in the organisation & 3.67 & 7 \\
\hline $\begin{array}{c}\text { Working with people who have the same values and approach } \\
\text { towards work }\end{array}$ & 3.66 & 8 \\
\hline Receiving and giving feedback on work performance & 3.64 & 9 \\
\hline Recognition and encouragement of my contribution & 3.62 & 10 \\
\hline A workplace with flexible work hours & 3.62 & 11 \\
\hline Emotional stability and feeling protected by the organisation & 3.61 & 12 \\
\hline An employer who encourages me to feel strong about who I am & 3.60 & 13 \\
\hline A workplace that is passionate about work & 3.58 & 14 \\
\hline A workplace with training programs & 3.55 & 15 \\
\hline Training in how to use new technology & 3.55 & 16 \\
\hline A workplace that has a high commitment to work & 3.54 & 17 \\
\hline $\begin{array}{c}\text { A workplace that is relaxed and people can have fun and enjoy } \\
\text { social interaction }\end{array}$ & 3.51 & 18 \\
\hline Having a say in decisions that affect day-to-day business & 3.39 & 19 \\
\hline A workplace that cares about protecting the environment & 3.37 & 20 \\
\hline A manager that focuses on management and administration & 3.21 & 21 \\
\hline High pay and income & 3.20 & 22 \\
\hline A high standard of accommodation and fit-out of the workplace & 3.13 & 23 \\
\hline A workplace that allows me to stay connected to my culture & 3.13 & 24 \\
\hline Paid on a salary basis, with a set annual income & 3.12 & 25 \\
\hline A manager who is aware of and responsive to my heritage and culture & 3.01 & 26 \\
\hline Being involved with my local community & 2.94 & 27 \\
\hline Travelling to different locations to perform my work duties & 2.66 & 28 \\
\hline Working extra hours (paid or unpaid) & 2.42 & 29 \\
\hline Paid by the hour & 2.19 & 30 \\
\hline Union membership & 1.77 & 31 \\
\hline
\end{tabular}




\subsection{Relationship between Construction Employment Outcomes and Social Value}

A test for Pearson's $r$ was also performed to check for an association between variables in the second and third sections. Pearson's $r$ is a measure of association that represents the extent to which respondents occupy the same position on two variables [60]. The strength of association between two variables may be small ( $r \geq \pm 0.10)$, medium $(r \geq \pm 0.30)$ or large $(r \geq \pm 0.50)$ [61]. In this study, Pearson's $r$ allowed the researchers to test for relationships between respondents' values and their EOC preferences. This allowed them to infer the work and cultural benefits that may contribute to positive social value creation in the context of construction employment. In total, there were seven large associations and 46 medium associations where the association was deemed to be significant $(p<0.05)$. Hence, in Table 6 , associations are reported where $r>0.35$ because there were many associations where $r<0.35$ and that many variables would take away from interpreting the stronger associations. It is interesting that the associations listed below were quite significant $(p<0.001)$, suggesting that the results were not obtained by chance and strengthening their validity.

Table 6. Association between work and culture values using Pearson's correlation coefficient (Pearson's r).

\begin{tabular}{|c|c|c|c|}
\hline Work Benefit & Cultural Benefit & Pearson's R & Sig. \\
\hline High pay and income & Making lots of money & 0.651 & 0.000 \\
\hline Being involved with my local community & Sharing with and looking after my community & 0.643 & 0.000 \\
\hline A workplace that allows me to stay connected to my culture & Making sure traditions, rituals, and practices are maintained & 0.595 & 0.000 \\
\hline $\begin{array}{c}\text { A manager who is aware of and responsive to my heritage } \\
\text { and culture }\end{array}$ & Sharing with and looking after my community & 0.576 & 0.000 \\
\hline Being involved with my local community & Making sure traditions, rituals, and practices are maintained & 0.541 & 0.000 \\
\hline A workplace that allows me to stay connected to my culture & Sharing with and looking after my community & 0.509 & 0.000 \\
\hline $\begin{array}{l}\text { A manager who is aware of and responsive to my heritage } \\
\text { and culture }\end{array}$ & Making sure traditions, rituals, and practices are maintained & 0.508 & 0.000 \\
\hline A workplace that cares about protecting the environment & Sharing with and looking after my community & 0.453 & 0.000 \\
\hline A high standard of accommodation and fit-out of the workplace & Making sure traditions, rituals, and practices are maintained & 0.444 & 0.000 \\
\hline Being involved with my local community & Staying connected with my wider relatives and community & 0.426 & 0.000 \\
\hline High pay and income & $\begin{array}{l}\text { Having possessions (like a house, car, and fashion items) to show } \\
\text { my status }\end{array}$ & 0.423 & 0.000 \\
\hline Paid by the hour & Making sure traditions, rituals, and practices are maintained & 0.421 & 0.000 \\
\hline High pay and income & Making sure I have enough for today & 0.416 & 0.000 \\
\hline Paid on a salary basis, with a set annual income & Making sure people know about my achievements & 0.402 & 0.000 \\
\hline A high standard of accommodation and fit-out of the workplace & Sharing with and looking after my community & 0.393 & 0.000 \\
\hline Union membership & Making sure traditions, rituals, and practices are maintained & 0.372 & 0.000 \\
\hline A workplace that has a high commitment to work & Sharing with and looking after my community & 0.370 & 0.000 \\
\hline A workplace that has a high commitment to work & Making sure traditions, rituals, and practices are maintained & 0.369 & 0.000 \\
\hline A workplace that cares about protecting the environment & Making sure traditions, rituals, and practices are maintained & 0.368 & 0.000 \\
\hline Being able to learn on the job & Making sure traditions, rituals, and practices are maintained & 0.367 & 0.000 \\
\hline Paid by the hour & $\begin{array}{l}\text { Having possessions (like a house, car, and fashion items) to show } \\
\text { my status }\end{array}$ & 0.356 & 0.000 \\
\hline Receiving and giving feedback on work performance & Finding things out and learning for myself & 0.356 & 0.000 \\
\hline High pay and income & Travelling widely and experiencing the world & 0.355 & 0.000 \\
\hline $\begin{array}{l}\text { A manager who is aware of and responsive to my heritage } \\
\text { and culture }\end{array}$ & Staying close to the place I was born & 0.353 & 0.000 \\
\hline Emotional stability and feeling protected by the organisation & Making sure traditions, rituals, and practices are maintained & 0.352 & 0.000 \\
\hline
\end{tabular}

Table 6 shows that, while the strongest correlation was between two variables that were capitalist and individualistic in that they are related to earning money, there are also several variables not linked to financial outcomes, such as helping employees stay connected to their culture, being engaged with communities, and maintaining rituals and practices. Maintaining rituals and practices indicates a preference for routinised, stable work, the lack of which, as Loosemore et al. [62] found, is a major risk to the success of new social procurement policies which will be applied to Australia's recent infrastructure commitments. Indeed, the larger representation of non-financial variables in Table 6 supports the notion that non-monetary factors influence employee motivation and performance [63]. It was interesting that 'having a say in decisions that affect day-to-day business' was ranked in the lower half of EOC preferences and was not among the strongest associations, in contrast with Pacheco and Webber's [47] finding that participative decision making is a critical factor in employee job satisfaction.

Testing for Pearson's correlation also allowed the researchers to test the construct validity of the survey. Construct validity refers to the validity of the construct being 
measured [59]; for example, if several questions measure the same or closely related thing, they should be highly correlated with one another. Table 6 shows that similar variables are correlated highly, with 'high pay and income' highly correlated to the value 'making lots of money'. Similarly, 'being involved with my local community' has a strong association to 'sharing with and looking after my community', thus indicating the survey has a high construct validity.

\subsection{Open-Ended Responses}

The open question at the end of the survey generated 64 responses. The purpose of the open question was to allow respondents to communicate the factors they thought will create social value. Qualitative responses were inductively coded in QSR International's NVivo software (version 12) to systematically identify themes from the data. Three broad themes were generated from this process, which are shown in the content analysis in Table 7. A fourth theme, 'safety', was initially generated based on the construction industry's poor safety record (see [64]). However, there was only one reference to safety in the qualitative responses, so it was removed from the content analysis in Table 7.

Table 7. Emergent themes from qualitative survey responses and content analysis.

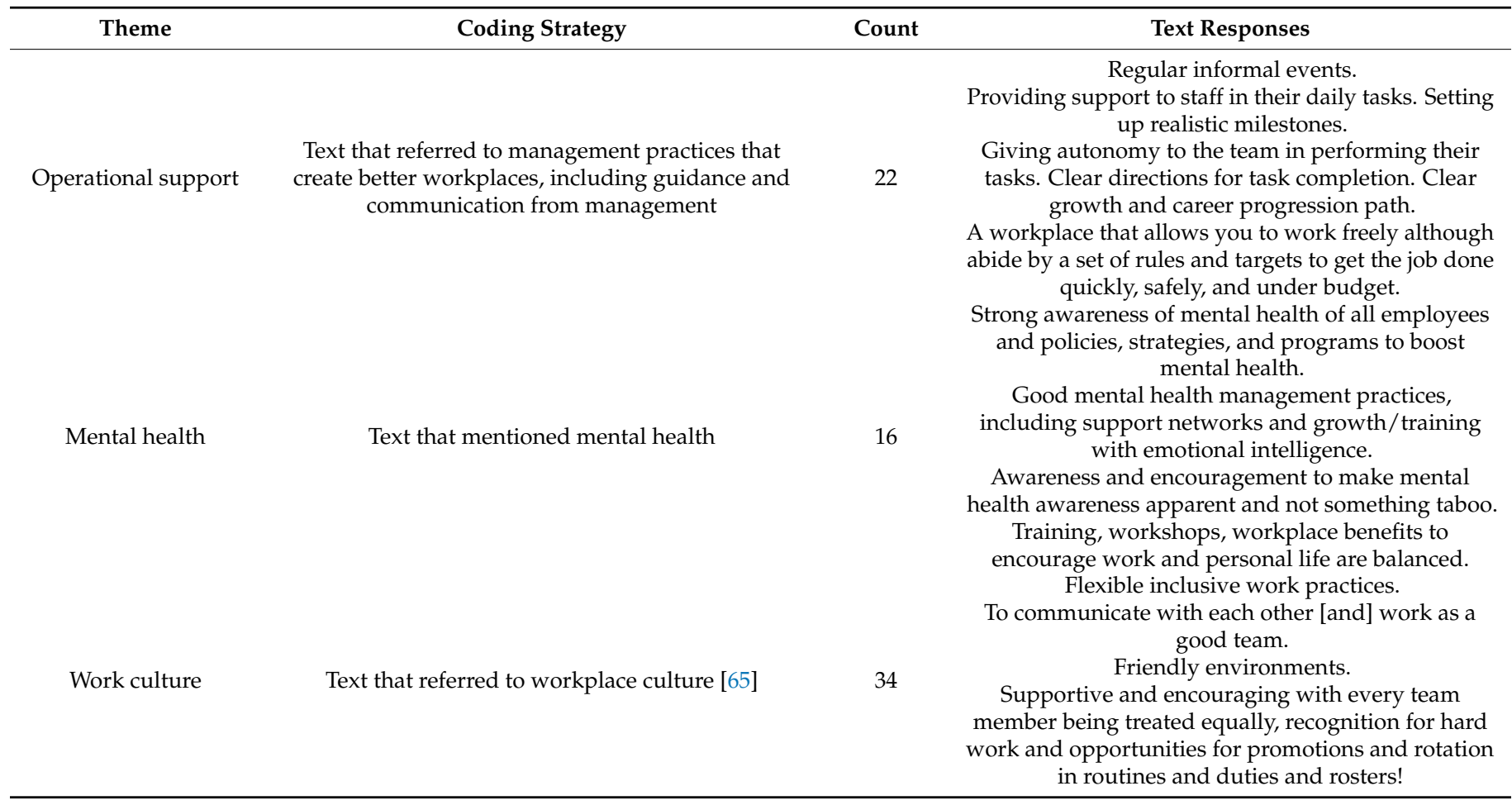

It is interesting in Table 7 that, while there were some responses that stated the importance of 'recognition for contribution' and hard work, there were no responses that spoke directly of being paid higher wages. This result is interesting because of recent research in China that found younger construction workers feel they do not get an adequate salary [65]. Although, the sample in that study was made up of young construction professionals who had not been in the industry for long and may have been impatient to see financial rewards. The findings in this study could be explained by Holden and Sunindijo's [66] review that found higher salaries are often the bargaining chip used to make Australian construction employees work longer, which is to the detriment of a work-life balance. Therefore, the four references to work-life balance under 'mental health' category (i.e., training, workshops, workplace benefits to encourage work and personal life are balanced) may be an indication that paying people a salary is not the only way to 
create social value through construction employment and that non-financial rewards are important to create the social and cultural impacts that contribute to social value.

\section{Discussion}

The results above show there are recurring variables that strongly influence other outcomes. For example, construction workplaces that were responsive to employees' cultures had a strong association with the importance of 'cultural benefits' of construction employment. In addition, values, like making sure traditions, rituals, and practices are maintained, had strong associations with numerous 'work benefits' like physical safety, emotional stability, and a workplace that is involved with local communities. Supporting Bae et al. [67], who found that clear communication and a sense of belonging were values important to American construction workers which leads to greater employee retention when those values are present in the workplace, these findings indicate that clear communication (respecting my elders and what they have to teach me) and a sense of belonging (sharing with and looking after my family) are important to creating social value in construction employment. Supporting Sedighi and Loosemore [52], who found the five highest-ranked workplace characteristics in their sample of construction management undergraduates were 'good quality of working relationships', 'being able to learn on the job', 'a workplace that is passionate about work', 'a relaxed, fun and social workplace', and 'seeing and understanding the purpose of tasks', this study's findings reinforce the importance of several workplace characteristics like to create social value. The theoretical implications of these findings are that policymakers could request contractors to implement certain training programs and initiatives on the large infrastructure projects that are currently planned. For practice, these relationships suggest that construction companies who want to create social value through employment may need to move beyond 'creating employment opportunities for people from disadvantaged communities' [15] (p. 73) and invest in the economic and cultural wellbeing of their employees and engage with the communities in which they build.

\subsection{Response to Research Questions}

The results above provide several useful insights that respond to the research questions the study aimed to answer. In response to the first research question, the findings indicate that a mixture of work benefits and cultural benefits that construction employment provides contribute to creating social value. The five highest values by mean score were 'sharing with and looking after my family', 'finding things out and learning for myself', 'making sure I have enough for today', 'knowing who I am and where I came from', and 'respecting my elders and what they have to teach $\mathrm{me}^{\prime}$. The five highest workplace characteristics by mean score that would contribute to social value were 'good quality of working relationships', 'seeing and understanding the overall purpose of tasks,' 'a good reputation', 'high level of personal physical safety', and 'being able to learn on the job'. At a macro level, policymakers can embed these insights into contractual requirements with contractors. At a micro level, these insights can be used directly in workplaces to create social value.

In response to the second research question, the findings highlight several correlations that could indicate work benefits and cultural benefits have some influence on the social value that construction employment can create. Grounded in the framework given by value theory above, acceptance of someone's work benefits and cultural benefit benefits will create social value. Therefore, it is suggested that when policymakers use their social procurement policies to target the work benefits and cultural benefits identified in Table 6, they will maximise the social value the policies create and help them achieve the goals to which social procurement policies aspire. Thus, in responding to the second research question, it is argued that there is a positive relationship between construction employment and social value when construction jobs provide the right work benefits and cultural benefits. 


\subsection{Creating Social Value through Construction Procurement}

For policymakers and practitioners who want to create social value through their procurement in response to COVID-19, this research gives several insights into how social value is created in the context of construction employment that they are currently stimulating. For example, culturally inclusive workplaces are clearly associated with numerous cultural benefits and there are more non-financial characteristics (e.g., emotional stability, learning on the job, and workplaces that are involved in local communities) of EOCs than financial. Indeed, this insight supports Murphy and Eadie's [68] findings that construction contractors need to adopt a more person-centric approach to generate social value through construction employment. The findings suggest that this could be done by familiarising staff recruited because of new social procurement policies with company routines and creating a workplace that encourages commitment to work, training, and employee development, as well as engagement with local communities. Indeed, the findings support recent work that argues creating social value requires a holistic approach to employment that supports the ways of knowing, being, and doing of the people intended to benefit from social procurement practices [33].

Synthesising the results of this research, Figure 2 identifies the work and cultural benefits that policymakers and construction employers can target so they create social value. The framework shows the process whereby social procurement policies lead to construction employment for the disadvantaged groups they target. The two areas of work and cultural benefits leading into construction employment show that there is a relationship between benefits and employment, in which employment creates the benefits but people's perceptions of employment opportunities are influenced by their values and workplace preferences. For example, increased employee autonomy and development is expected to contribute to an inclusive work environment, and hence social value creation, because greater employee involvement leads to a better work environment [48].

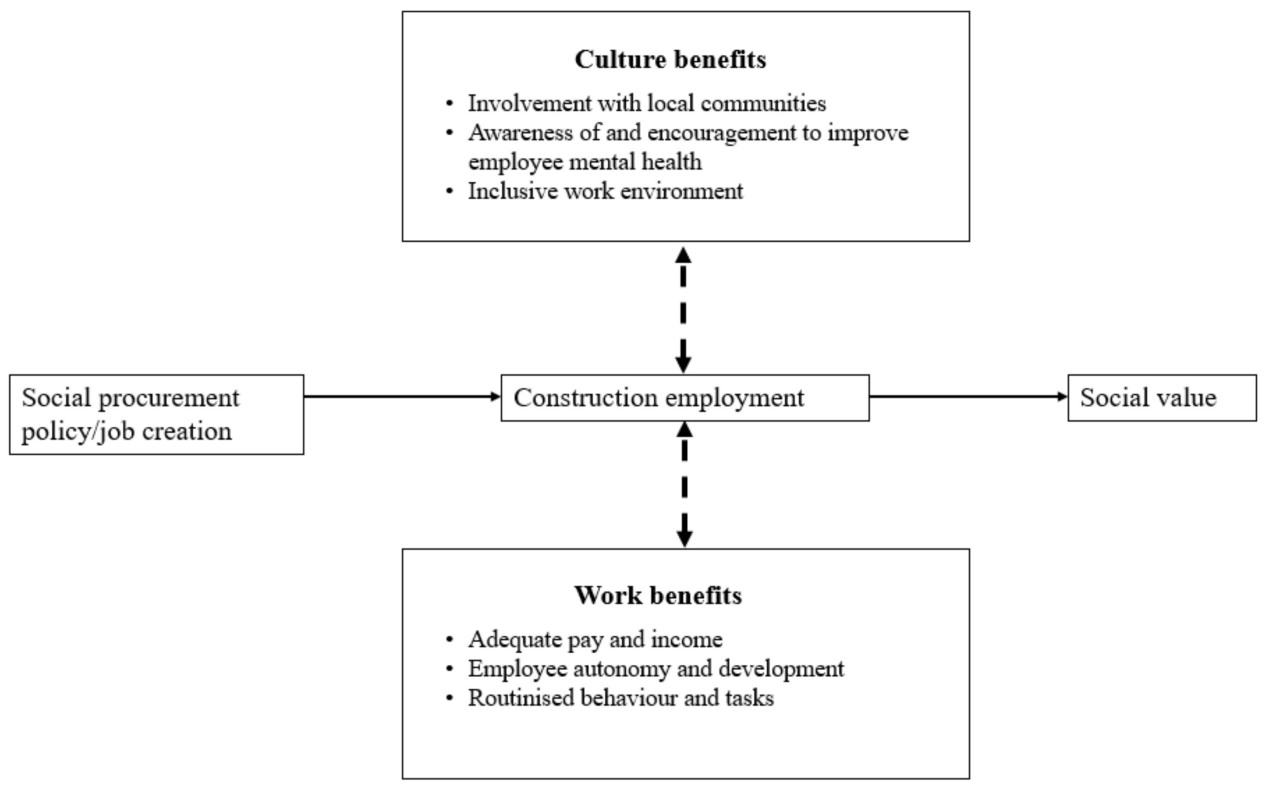

Figure 2. A framework to create social value through employment.

Indeed, for people who have become unemployed due to COVID-19 or already faced employment difficulties prior to the pandemic, creating workplaces in the construction industry based on these social value insights will contribute to the economic and social recovery from COVID-19. For example, people who became unemployed because of the pandemic could easily gain work in the construction industry because of its low entry barriers and social procurement requirements that are being applied to publicly funded construction projects. People who get the construction jobs because of new social 
procurement requirements will not have to rely on social welfare and unemployment benefits to meet their daily living needs, and if they enter a workplace that maximises the outcomes presented in this paper, they are likely to experience positive social value as a result, which has broader effects in their communities. Such outcomes repeated on the many construction sites in Australia will contribute to Australia's economic and social recovery from COVID-19.

The framework can benefit diverse stakeholders who implement, and are affected by, social procurement policies. For example, government departments can refer to the framework to inform policy development and evaluation. This includes inserting clauses into contracts that require contractors to implement certain practices that create the work benefits presented in Figure 2. Contractors can also use the framework to develop social procurement practices or evaluate what they are currently doing. For example, contractors can review whether their employment practices and work environment are creating the types of benefits that create social value. This includes the training and employment opportunities they have provided, and the new networks and suppliers established in their supply chain. Communities can use the framework to assert their concerns with governments and contractors. This should leave communities in a better position to use the current infrastructure boom in Australia to ensure better training and employment opportunities for local people.

At an operational level, 'adequate pay and income' refers to construction employees being paid enough to meet their basic needs. It is suggested that adequate pay and income means that staff are at least paid at award wages and not exploited out of less money, and the authors are aware that most construction contractors should already be complying with this outcome. Encouraging autonomy and development acknowledges that respondents preferred being able to work freely and with the autonomy to complete their tasks. The outcome of autonomy is balanced by respondents' preference to be given clear instructions and a set of rules to complete tasks, as seen in the benefit of routinised behaviour and tasks.

Policymakers wanting to include the benefits in Figure 2 could insert them into policy documents that become contract clauses. For example, they could be used to put specific employment practices in New South Wales' Aboriginal Participation in Construction policy [69] or Victoria's Social Procurement Framework [19] that would require contractors to report on their community engagement or efforts to promote mental health in the workforce. These findings suggest that such clauses are likely to promote the collaborative, bottom-up approaches that are argued to be more successful in realising the social outcomes and value that social procurement policies aspire to [62].

From an employee satisfaction perspective, this research also contributes to EOC research that seeks to understand an ideal employer. These findings reinforce Rampl [46], who found that EOCs are determined by the work content and work culture they provide. These findings indicate that positive work content is created through work benefits like pay, income, and employee autonomy. Positive work culture is created through workplace relationships with local communities, attention to employee mental health, and an inclusive work environment. Further, and in support of Bellou et al. [44], these findings emphasise the importance of self-development, workplace relationships, and remuneration to EOC scholarship. Drawing on the Indigenous values that have informed this study, such characteristics are a form of reciprocity, where employers invest in the wellbeing and development of staff, and employees reciprocate by investing in the success of the business through output and productivity, which creates social value; these lessons could be applied to businesses in Australia and internationally.

\subsection{Limitations}

One limitation of this paper is that it does not provide a universal solution to creating social value. This research therefore does not attempt to be universally applicable; the authors acknowledge that the research is limited to Australia and a limited sample. In other countries that have experienced the economic and social crises of COVID-19 differently, 
such as New Zealand with fewer cases and the UK and US with much more cases, the application and effectiveness of these findings may differ significantly. Furthermore, in countries like Italy, investments in the 'green' sector and renewable energy sources are creating employment opportunities and reducing the economic impact of COVID-19 [70] and may offer different results to those presented in this study. This limits its contribution as a major theoretical framework but as it is tested over time its validity will improve. Indeed, the survey used in this study can be repeated in other industries to understand how social value is created in different contexts.

Implementing this framework on the new infrastructure projects committed to by Australian governments may also experience difficulties at first. Many contractors and subcontractors see the groups targeted by social procurement policies as a significant safety, productivity, and cost risk to their business [62]. At the same time, there has been little convergence of social procurement practices in construction due to practices not being fully internalised across organisations and projects, people hired through social procurement do not have strong enough incentives to engage with their employment, actors working strategically and operatively have different opportunities to create social procurement practices, and the development of maintenance mechanisms for the formalisation of sustainable practices is weak [71], while social procurement is also creating new roles for construction practitioners that are still in their genesis and under-researched [35]. Further research is needed in this area to explore how contractors are utilising their employment to create social value for employees if the economic and social recovery from COVID-19 is to be sustainable.

\section{Conclusions}

COVID-19 has had significant economic and social impacts on societies internationally. The response by governments in Australia has been to increase already buoyant public infrastructure spending to stimulate economic activity and use social procurement policies to get Australia out of these crises through an 'infrastructure-led recovery' [72]. At the same time, the role of procurement has been changing to include economic and social objectives mandated by government clients [16,73], which has changed the roles and objectives of contractors to create social value in the communities in which they build. Recognising this context and filling a current gap in knowledge about how employment can create social value to help economies recover from COVID-19, this empirical paper presented theoretical and practical guidance for contractors to create social value in their business. It is argued that construction employment will create social value when employers provide work benefits like good pay and remuneration and training and development opportunities, and cultural benefits like employee autonomy and an inclusive workplace. This supports arguments that employee participation and holistic focuses on socially responsible procurement are key to creating social value [68]. Operationalising frameworks, like the one proposed in this paper, and using it to evaluate how workplaces have adapted in response to COVID-19 will lead to the research and data innovations required to meet the Sustainable Development Goals, outlined by the United Nations [26], by improving existing data gaps on progress towards 'Goal 8: Decent work and economic growth'. The results also respond to recent scholarship that has begun to explore how social value can be conceptualised and operationalised in the construction industry [15]. By implementing this research in practice, governments and employers can improve the likelihood of creating social value through employment and assisting the economic and social recovery from COVID-19.

Author Contributions: Conceptualisation, G.D.-S., R.Y.S. and M.L.; methodology, G.D.-S., M.L. and R.Y.S.; software, G.D.-S.; validation, G.D.-S., R.Y.S., M.L. and L.P.; formal analysis, G.D.-S.; investigation, G.D.-S.; resources, G.D.-S., R.Y.S., M.L., M.W. and L.P.; data curation, G.D.-S.; writingoriginal draft preparation, G.D.-S. and R.Y.S.; writing-review and editing, G.D.-S., R.Y.S., M.L., M.W. and L.P.; visualisation, G.D.-S.; supervision, R.Y.S., M.L., L.P. and M.W.; project administration, G.D.-S. Please turn to the CRediT taxonomy for the term explanation. All authors have read and agreed to the published version of the manuscript. 
Funding: This research received no external funding.

Institutional Review Board Statement: This research was approved by the UNSW Human Research Ethics Committee (HC190665, approved 1 October 2019).

Informed Consent Statement: Informed consent was obtained from all participants in this research.

Data Availability Statement: Other than the results presented in this manuscript, data are not publicly available due to conditions of ethical approval from the UNSW Human Research Ethics Committee.

Acknowledgments: The authors would like to thank their industry stakeholders in the Australian construction industry for their efforts to promote this research.

Conflicts of Interest: The authors declare no conflict of interest.

\section{References}

1. Lowe, P. COVID, Our Changing Economy and Monetary Policy. In Committee for Economic Development of Australia Annual Dinner Address; Reserve Bank of Australia: Sydney, Australia, 2020. Available online: https://www.rba.gov.au/speeches/2020/sp-gov2020-11-16.html (accessed on 10 December 2020).

2. ABS. Labour Force, Australia August 2020. Australian Bureau of Statistics: Canberra. 2020. Available online: https://www.abs. gov.au/statistics/labour/employment-and-unemployment/labour-force-australia/aug-2020 (accessed on 24 September 2020).

3. Community Affairs References Committee. Adequacy of Newstart and Related Payments and Alternative Mechanisms to Determine the Level of Income Support Payments in Australia; Australian Senate: Canberra, Australia, 2020.

4. O'Sullivan, D.; Rahamathulla, M.; Pawar, M. The impact and implications of COVID-19: An Australian perspective. Int. J. Community Soc. Dev. 2020, 2, 134-151. [CrossRef]

5. Crooks, K.; Casey, D.; Ward, J.S. First Nations peoples leading the way in COVID-19 pandemic planning, response and management. Med. J. Aust. 2020, 213, 151. [CrossRef] [PubMed]

6. Alon, I.; Farrell, M.; Li, S. Regime type and COVID-19 response. FIIB Bus. Rev. 2020, 9, 152-160. [CrossRef]

7. Kraus, S.; Clauss, T.; Breier, M.; Gast, J.; Zardini, A.; Tiberius, V. The economics of COVID-19: Initial empirical evidence on how family firms in five European countries cope with the corona crisis. Int. J. Entrep. Behav. Res. 2020, 26, 1067-1092. [CrossRef]

8. Ratten, V. Coronavirus (covid-19) and social value co-creation. Int. J. Sociol. Soc. Policy 2020. [CrossRef]

9. Bacq, S.; Geoghegan, W.; Josefy, M.; Stevenson, R.; Williams, T.A. The COVID-19 virtual idea blitz: Marshalling social entrepreneuship to rapidly respond to urgent grand challenges. Bus. Horiz. 2020, 63, 705-723. [CrossRef]

10. Commonwealth of Australia. Infrastructure Investment Program; Department of Infrastructure, Transport, Regional Development and Communications: Canberra, Australia, 2020. Available online: https://investment.infrastructure.gov.au/ (accessed on 14 December 2020).

11. Australian Government. Shovel Ready Projects. Australian Government: Canberra, Australia. 2020. Available online: https://investment.infrastructure.gov.au/infrastructure_investment/infrastructure_investment_response_covid-19/shovel_ ready_projects.aspx (accessed on 14 September 2020).

12. Australian Government. Rail to Western Sydney Airport; Australian Government: Canberra, Australia, 2020. Available online: https:/ / www.westernsydneyairport.gov.au/transport-infrastructure/rail (accessed on 14 September 2020).

13. Queensland Government. Queensland's Economic Recovery Plan; Queensland Government: Brisbane/Adelaide, Australia, 2020.

14. Infrastructure, S.A. Capital Intentions Statement 2020; Infrastructure SA: Adelaide, Australia, 2020.

15. Raiden, A.; Loosemore, M.; King, A.; Gorse, C. Social Value in Construction; Routledge: London, UK, 2019.

16. Barraket, J.; Keast, R.; Furneaux, C. Social Procurement and New Public Governance; Routledge: Oxon, UK, 2015.

17. Furneaux, C.; Barraket, J. Purchasing social good(s): A definition and typology of social procurement. Public Money Manag. 2014, 34, 265-272. [CrossRef]

18. Australian Government. Commonwealth Indigenous Procurement Policy: 1 July 2015; Australian Government: Canberra, Australia, 2015.

19. Victorian Government. Victoria's Social Procurement Framework: Building a Fair, Inclusive and Sustainable Victoria through Procurement; Victorian Government: Melbourne, Australia, 2018.

20. NIAA. Procurement Policy Brings \$3.5 Billion in Contracts to Indigenous Businesses; National Indigenous Australians Agency: Canberra, Australia, 2020. Available online: https://www.niaa.gov.au/news-centre/indigenous-affairs/procurement-policybrings-3point5-billion-contracts-indigenous-businesses (accessed on 10 December 2020).

21. Mulgan, G. Measuring social value. Stanf. Soc. Innov. Rev. 2010, 8, 38-43.

22. Loosemore, M.; Denny-Smith, G.; Barraket, J.; Keast, R.; Chamberlain, D.; Muir, K.; Powell, A.; Higgon, D.; Osborne, J. Optimising social procurement policy outcomes through cross-sector collaboration in the Australian construction industry. ECAAM 2020. [CrossRef]

23. Troje, D. Can I Get Some Help Down Here? Inter-Project Support for Creating Social Value through Social Procurement. In Proceedings of the 36th Annual ARCOM Conference, Glascow, UK, 7-8 September 2020; Scott, L., Neilson, C.J., Eds.; Association of Researchers in Construction Management: Manchester, UK, 2019; pp. 105-114. 
24. Abowen-Dake, R.; Higham, A.P.; Farrell, P.; Watts, G.N. Social Value Practices in Housing Associations' Construction Procurement in North West England. In Proceedings of the ARCOM 2020: Building a Common Good in Construction, Glasgow, UK, 7-8 September 2020.

25. Watts, G.; Dainty, A.; Fernie, S. Measuring Social Value in Construction. In Proceedings of the 35th Annual ARCOM Conference, Leeds, UK, 2-4 September 2019; Gorse, C., Neilson, C.J., Eds.; Association of Researchers in Construction Management: Manchester, UK, 2019; pp. 54-63.

26. United Nations. The Sustainable Development Goals Report 2020; United Nations: New York, NY, USA, 2008.

27. PwC Australia. Australia Rebooted; PwC Australia: Sydney, Australia, 2020.

28. McCrudden, C. Using public procurement to achieve social outcomes. Nat. Resour. Forum 2004, 28, 257-267. [CrossRef]

29. Barraket, J. The Role of Intermediaries in Social Innovation: The Case of Social Procurement in Australia. J. Soc. Entrep. 2019, 11, 194-214. [CrossRef]

30. McCrudden, C. Buying Social Justice: Equality and Public Procurement. Curr. Leg. Probl. 2007, 60, 121-147. [CrossRef]

31. Loosemore, M. Social procurement in UK construction projects. Int. J. Proj. Manag. 2016, 34, 133-144. [CrossRef]

32. Fewings, P.; Henjewele, C. Construction Project Management: An Integrated Approach, 3rd ed.; Routledge: Abingdon, UK, 2019.

33. Denny-Smith, G.; Williams, M.; Loosemore, M. Assessing the impact of social procurement policies for Indigenous people. Constr. Manag. Econ. 2020, 38, 1139-1157. [CrossRef]

34. Troje, D.; Kadefors, A. Employment requirements in Swedish construction procurement-Institutional perspectives. J. Facil. Manag. 2018, 16, 284-298. [CrossRef]

35. Troje, D.; Gluch, P. Populating the social realm: New roles arising from social procurement. Constr. Manag. Econ. 2020, 38, 55-70. [CrossRef]

36. Nicholls, A. A General Theory of Social Impact Accounting: Materiality, Uncertainty and Empowerment. J. Soc. Entrep. 2018, 9, 132-153. [CrossRef]

37. Denny-Smith, G.; Loosemore, M.; Barwick, D.; Sunindijo, R.; Piggott, L. Decolonising Indigenous Social Impact Research using Community-Based Methods. In Proceedings of the 35th Annual ARCOM Conference, Leeds, UK, 2-4 September 2019; Gorse, C., Neilson, C.J., Eds.; Association of Researchers in Construction Management: Manchester, UK, 2019; pp. 64-73.

38. Haugh, H. The importance of theory in social enterprise research. Soc. Enterp. J. 2012, 8, 7-15. [CrossRef]

39. Meinong, A. Psychological-Ethical Investigations to Value; Leuschner \& Lubensky: Graz, Austria, 1894.

40. Denny-Smith, G.; Loosemore, M. A Theoretical Framework of Social Value in Construction Employment. In Proceedings of the 36th Annual ARCOM Conference, Glasgow, UK, 7-8 September 2020; Scott, L., Neilson, C.J., Eds.; Association of Researchers in Construction Management: Manchester, UK, 2020; pp. 45-54.

41. Elving, W.J.L.; Westhoff, J.J.C.; Meeusen, K.; Schoonderbeek, J.-W. The war for talent? The relevance of employer branding in job advertisements for becoming an employer of choice. J. Brand Manag. 2013, 20, 355-373. [CrossRef]

42. Branham, L. Planning to become an employer of choice. J. Organ. Excel. 2005, 24, 57-68. [CrossRef]

43. Kucherov, D.; Zavyalova, E. HRD practices and talent management in the companies with the employer brand. Eur. J. Train. Dev. 2012, 36, 86-104. [CrossRef]

44. Bellou, V.; Chaniotakis, I.; Kehagias, J.; Rigopoulou, I. Employer brand of choice: An employee perspective. J. Bus. Econ. Manag. 2015, 16, 1201-1215. [CrossRef]

45. Aboul-Ela, G.M.B.E.D. Employer branding: What constitutes an employer of choice? J. Bus. Retail Manag. Res. 2016, 11, 154-166.

46. Rampl, L.V. How to become an employer of choice: Transforming employer brand associations into employer first-choice brands. J. Mark. Manag. 2014, 30, 1486-1504. [CrossRef]

47. Pacheco, G.; Webber, D. Job satisfaction: How crucial is participative decision making? Pers. Rev. 2016, 45, 183-200. [CrossRef]

48. García, G.A.; Gonzales-Miranda, D.R.; Gallo, O.; Roman-Calderon, J.P. Employee involvement and job satisfaction: A tale of the millennial generation. Empl. Relat. 2019, 41, 374-388. [CrossRef]

49. NHMRC. Ethical Conduct in Research with Aboriginal and Torres Strait Islander Peoples and Communities: Guidelines for Researchers and Stakeholders; National Health and Medical Research Council: Canberra, Australia, 2018.

50. AIATSIS. AIATSIS Code of Ethics for Aboriginal and Torres Strait Islander Research; Australian Institute of Aboriginal and Torres Strait Islander Studies: Canberra, Australia, 2020.

51. Hunter, B. Whose business is it to employ Indigenous workers? Econ. Labour Relat. Rev. 2015, 26, 631-651. [CrossRef]

52. Sedighi, F.; Loosemore, M. Employer-of-choice characteristics in the construction industry. Constr. Manag. Econ. 2012, 30, 941-950. [CrossRef]

53. Dillman, D.A.; Smyth, J.D.; Christian, L.M. Internet, Mail, and Mixed-Mode Surveys: The Tailored Design Method, 3rd ed.; John Wiley \& Sons: Hoboken, NJ, USA, 2009.

54. Byrnes, J. A comparison of Aboriginal and non-Aboriginal values. Dissent 2000, 3, 6-11.

55. Nardi, P.M. Doing Survey Research: A Guide to Quantitative Methods; Pearson Education: Boston, MA, USA, 2003.

56. Aupperle, K.E.; Carroll, A.B.; Hatfield, J.D. An empirical examination of the relationship between corporate social responsibility and profitability. Acad. Manag. J. 1985, 28, 446-463.

57. Austen, S. Culture and the labour market. Rev. Soc. Econ. 2000, 58, 505-521. [CrossRef]

58. Wilson, B.; Abbott, T.; Quinn, S.J.; Guenther, J.; McRae-Williams, E.; Cairney, S. Empowerment is the Basis for Improving Education and Employment Outcomes for Aboriginal People in Remote Australia. Aust. J. Indig. Educ. 2019, 48, 153-161. [CrossRef] 
59. Fowler, F.J. Improving Survey Questions: Design and Evaluation; Applied Social Research Methods Series, 38; Sage: Thousand Oaks, CA, USA, 1995.

60. Blaikie, N. Analyzing Quantitative Data; Sage: London, UK, 2003.

61. Rosenthal, J.A. Qualitative Descriptors of Strength of Association and Effect Size. J. Soc. Serv. Res. 1996, 21, 37-59. [CrossRef]

62. Loosemore, M.; Alkilani, S.; Mathenge, R. The risks of and barriers to social procurement in construction: A supply chain perspective. Constr. Manag. Econ. 2020, 38, 552-569. [CrossRef]

63. Sukumaran, A.K.S. The endowment effect in the preference for non-monetary motivational factors. Int. J. Bus. Inf. Syst. 2020, 33, 472-487.

64. Loosemore, M.; Sunindijo, R.Y.; Lestari, F.; Kusminanti, Y.; Widanarko, B. Comparing the safety climate of the Indonesian and Australia construction industries. Eng. Constr. Archit. Manag. 2019, 26, 2206-2222. [CrossRef]

65. Song, Z.; Yang, F.; Boezeman, E.J.; Li, X. Do new-generation construction professionals be provided what they desire at work? A study on work values and supplies-Values fit. Eng. Constr. Arch. Manag. 2020, 27, 2835-2858. [CrossRef]

66. Holden, S.; Sunindijo, R.Y. Technology, Long Work Hours, and Stress Worsen Work-life Balance in the Construction Industry. Int. J. Integr. Eng. 2018, 10, 13-18. [CrossRef]

67. Bae, H.; McCall, C.; Simmons, D.R. Investigating Work, Cultural and Life Values of Construction Employees. In Proceedings of the 55th ASC Annual International Conference, Denver, CO, USA, 10-13 April 2018; pp. 637-644.

68. Murphy, M.; Eadie, R. Socially responsible procurement: A service innovation for generating employment in construction. Built Environ. Proj. Asset Manag. 2019, 9, 138-152. [CrossRef]

69. NSW Government. NSW Government Policy on Aboriginal Participation in Construction; NSW Department of Finance, Services and Innovation: Sydney, Australia, 2016.

70. Dell'Anna, F. Green jobs and energy efficiency as strategies for economic growth and the reduction of environmental impacts. Energy Policy 2020, 112031. [CrossRef]

71. Troje, D.; Andersson, T. As above, not so below: Developing social procurement practices on strategic and operative levels. Equal. Divers. Incl. Int. J. 2020. [CrossRef]

72. Transport and Infrastructure Council. Communique of 13th Meeting of the Transport and Infrastructure Council of the Council of Australian Governments; Transport and Infrastructure Council: Canberra, Australia, 2020. Available online: https:/ / www.transportinfrastructurecouncil.gov.au/sites/default/files/documents/13th-transport-and-infrastructurecouncil-communique.pdf (accessed on 10 November 2020).

73. APCC. Future Procurement Skill Requirements: A More Strategic Procurement Approach; Australasian Procurement and Construction Council: Deakin, Australia, 2018. 